\title{
KARAKTER GENETIK INDUK (F-0) DAN TURUNANNYA (F-1) PADA IKAN HIAS LAUT CLOWN(Amphiprion percula) MENGGUNAKAN MARKER RAPD (Random Amplified Polymorfism DNA)
}

\author{
Sari Budi Moria Sembiring, Ketut Maha Setiawati, Haryanti, dan \\ Ida Komang Wardana \\ Balai Besar Riset Perikanan Budidaya Laut \\ Jl. Br. Gondol, Kec. Gerokgak, Kab. Buleleng-Kotak Pos 140 \\ E-mail: moriasembiring@yahoo.co.id
}

(Naskah diterima: 8 April 2010; Disetujui publikasi: 26 April 2010)

\begin{abstract}
ABSTRAK
Studi analisis karakter genetik ikan hias laut clown menggunakan metode penanda DNA RAPD dilakukan dalam upaya membantu pengembangan perbenihan dan budidaya ikan hias laut clown di Indonesia. Tujuan penelitian ini adalah untuk mendeterminasi karakter genetik dengan menggunakan analisis individu dari populasi induk (F-0) dan turunannya ( $\mathrm{F}-1)$ sehingga diperoleh tingkat penurunan keragaman genetik dan keterkaitannya dengan karakter morfologi. Sampel yang dianalisis terdiri atas 5 pasang induk ikan clown (10 sampel) dan masing-masing turunannya sebanyak 10 ekor (50 sampel) sehingga total 60 sampel. Nilai rata-rata keragaman genetik induk ikan clown dari semua lokus primer sebesar 0,253, sedangkan pada turunannya ( $F-1)$ adalah 0,157 . Hal ini menggambarkan adanya pengaruh genetik terhadap perbedaan pola pemunculan band putih.
\end{abstract}

KATA KUNCl: karakter genetik, ikan hias laut clown, penanda RAPD

ABSTRACT: Genetic characteristic of broodstock (F-O) and its generation (F-1) of clownfish (Amphiprion percula) analyzed using Random Amplified Polymorfism DNA (RAPD) marker. By: Sari Budi Moria Sembiring, Ketut Maha Setiawati, Haryanti, and Ida Komang Wardana

Study genetic characteristic of clownfish, Amphiprion percula using RAPD DNA marker was conducted in order to support development of breeding and culture program of marine ornamental clownfish in Indonesia. The objective of this research was to determine of genetic characteristic of clown fish using individual analysis from $F-0$ population and its generations ( $F-1)$ to find specific marker which is related to its morphology. Total samples analyzed were 60, consist of 5 pairs of clownfish broodstock (10 samples) and 10 ind each generations (50 samples). Mean value of genetic diversity of clown fish broodstock from all primer loci was 0.253, while on its generation F-1 was 0.157 . This result showed there was effect of genetic on the differences of white band pattern appearance.

KEYWORDS: genetic characteristic, clown fish, RAPD marker 


\section{PENDAHULUAN}

Indonesia merupakan negara terkaya akan keragaman jenis ikan hias laut (253 jenis) dibandingkan dengan negara penghasil ikan hias laut seperti Sri Langka 165 jenis, Philipina 112 jenis, Kenya 95 jenis, Amerika Serikat (Hawai) 65 jenis, Puerto Rico 49 jenis, Muangthai 45 jenis, dan Singapura 32 jenis (Martosewojo et al., 1985). Meskipun potensi ikan hias laut Indonesia cukup besar, tetapi dengan kondisi terumbu karang saat ini yang makin memprihatinkan akibat penangkapan ikan dan udang karang dengan cara dan alat yang tidak ramah lingkungan, maka keberadaan ikan hias dikhawatirkan juga akan berkurang.

Sehubungan dengan hal tersebut, maka perlu segera dilakukan kegiatan konservasi dan rehabilitasi terumbu karang sebagai habitat ikan hias laut. Di samping itu, perlu pula dilakukan upaya-upaya ke arah domestikasi dan perbenihan ikan hias laut sehingga pasokan ikan hias tidak sepenuhnya tergantung pada habitat terumbu karang, dengan demikian tekanan terhadap ekosistem terumbu karang akan dapat dikurangi.

Salah satu jenis ikan hias laut yang sudah berhasil dalam perbenihannya di Balai Besar Riset Perikanan Budidaya Laut Gondol, Bali adalah ikan hias laut jenis clown (Amphiprion percula). Hasil penelitian perbenihan ikan hias clown ini menunjukkan bahwa sebagian benih yang dihasilkan mempunyai pola warna yang tidak sesuai dengan induknya, walaupun ukurannya telah memenuhi syarat sebagai ikan hias (3-4 cm). Benih yang dihasilkan mempunyai berbagai ragam pola warna seperti band putih pada bagian badan dan ekor yang tidak tersambung/setengah badan atau band putih pada ekor tidak muncul. Kemungkinan perbedaan ini dapat ditelusuri melalui pendekatan perkembangan morfologi dan penggunaan marker DNA.

Dalam proses pembenihan dan budidaya ikan hias clown, salah satu aspek yang perlu dicermati adalah karakterisasi karakter genetik dari induk ( $F-0)$ dan turunannya ( $F-1)$ sehingga ke depan proses pembenihan dan budidaya dapat dilakukan secara kontinu. Penurunan keragaman genetik akibat hilangnya alelalel langka dari hasil perbenihan dapat menghambat pertumbuhan, rentan terhadap serangan penyakit dan perubahan lingkungan serta terjadinya abnormalitas benih yang dihasilkan (Leary et al., 1984). Oleh karena itu, upaya penelusuran karakter genetik dari induk F-0 pada turunannya (F-1) pada tingkat molekular perlu dilakukan untuk memperoleh mutu benih yang berkualitas baik secara fenotip maupun genotip.

Random Amplified Polymorphism DNA (RAPD) merupakan salah satu teknik molekular yang sangat luas digunakan dalam studi struktur genetik populasi dan pengukuran terhadap variasi genetik dari suatu populasi organisme. Jumlah dan distribusi dari variasi genetik merefleksikan terjadinya interaksi antara proses yang terlibat dalam evolusi seperti aliran gen, mutasi, dan genetic drift (Nkongolo et al., 2002).

Penelitian ini bertujuan untuk mendeterminasi karakter genetik dengan menggunakan analisis individu dari populasi F-0 dan turunannya (F-1) pada ikan clown dengan metode DNA-RAPD sehingga diperoleh informasi keterkaitan karakter genotipe dengan performansi karakter morfologi yang diindikasikan dari pemunculan pola band pada ikan tersebut.

\section{BAHAN DAN METODE}

\section{Sampel Ikan Hias Clown, Amphiprion percula}

Ikan hias clown yang digunakan sebagai sampel uji dalam penelitian ini adalah ikan hias clown yang merupakan hasil pembenihan dari Balai Besar Riset Perikanan Budidaya Laut, Gondol dan CV Dinar di Denpasar. Sampel yang dianalisis terdiri atas 5 pasang induk (kode PT-2; PT-3; PT-5; PT-9; dan PT-10), dan 10 ekor F-1 dari masing-masing pasangan induk sehingga total sampel sebanyak 60 ekor. Rata-rata ukuran panjang F-1 untuk semua sampel masing-masing berkisar antara 1,60$3,36 \mathrm{~cm}$; sedangkan ukuran bobot berkisar antara 0,17-1,12 g. Pengamatan pola band putih pada bagian kepala, badan, dan ekor dilakukan pada semua sampel induk dan turunannya.

\section{Ekstraksi dan Purifikasi DNA}

DNA ikan hias clown diekstraksi dari daging dan sirip dengan metode Ovenden (2000) yang telah dimodifikasi menggunakan Chelex $^{\mathrm{TM}}-100$ dan Protein Kinase 20 mg $/ \mathrm{mL}$. Hasil ekstraksi DNA selanjutnya dipurifikasi menggunakan Qiaquick Purification DNA Kit (Roche). Larutan DNA yang dihasilkan disimpan 
dalam suhu $-20^{\circ} \mathrm{C}$ sebelum digunakan pada tahap selanjutnya. Kuantitas dan kemurnian DNA dari masing-masing sampel diukur dengan menggunakan spektrofotometer pada panjang gelombang $260 \mathrm{~nm}$ dan $280 \mathrm{~nm}$. Pembacaan $A_{m}=1$ berarti konsentrasi DNA adalah $50 \mu \mathrm{g} / \mathrm{mL}$ dan dianggap sebagai faktor konversi. Kemurnian DNA ditetapkan berdasarkan nilai rasio $A_{260} / A_{280}$ sekitar 1,8-2,0 (Sambrook et al., 1989).

\section{Reaksi Amplifikasi dan Elektroforesis}

Reaksi amplifikasi menggunakan Taq DNA Polymerase (Qiagen). Volume reaksi yang digunakan dalam analisis RAPD ini adalah $25 \mu \mathrm{L}$ yang terdiri atas $10 \mathrm{x}$ bufer reaksi $(10$ $\mathrm{mM} \mathrm{MgC1} 1_{2}$ ); 2,5 mM dNTP; 1 unit Taq DNA polimerase; 50 -100ng DNA template dan $10 \mu \mathrm{M}$ primer (10-mer kit Operon) dengan menggunakan mesin PCR PC-960C dan PTC200. Program siklus termal adalah: suhu pemanasan awal pada $93^{\circ} \mathrm{C}$ selama 5 menit diikuti dengan 45 siklus reaksi yang masingmasing terdiri atas reaksi denaturasi DNA $\left(92^{\circ} \mathrm{C}\right.$ selama 1 menit), reaksi penempelan primer (annealing) pada suhu $35^{\circ} \mathrm{C}$ selama 2 menit, dan pemanjangan DNA (extention) pada suhu $72^{\circ} \mathrm{C}$ selama 3 menit. Siklus PCR diakhiri pada suhu $72^{\circ} \mathrm{C}$ selama 10 menit untuk melengkapi proses pemanjangan DNA.

Pada reaksi amplifikasi ini bertujuan untuk menyeleksi primer yang dapat menghasilkan produk amplifikasi. Amplifikasi DNA untuk menyeleksi primer yang sesuai dilakukan dengan menggunakan 21 primer acak (10-mer) dari Operon yaitu: OPA-01, OPA-02, OPA-03, OPA-04, OPA-05, OPA-06, OPA-07, OPA-08, OPA09, OPA-10, OPA-11, OPA-12, OPA-13, OPF-01, OPF-02, OPF-04, OPF-05, OPF-06, OPF-07, OPF09 dan OPF-14. Selanjutnya analisis RAPD dilakukan pada 60 sampel ikan clown yang DNA-nya telah diisolasi.

DNA hasil amplifikasi kemudian ditambahkan 2 x loading buffer dan dielektroforesis bersama DNA standar $100 \mathrm{bp}$ DNA Ladder (Biolabs) pada 1,5\% gel agarose dalam 1x TBE buffer dan diwarnai ethidium bromide pada kondisi voltase konstan 50-70 volt selama 1 jam 25 menit. Hasil elektroforesis divisualisasikan di atas UV transiluminator dan untuk dokumentasi menggunakan Biodoc $\mathrm{Gel}$ Camera.

\section{Analisis Data}

Data yang diperoleh dari pemotretan gel hasil RAPD berupa pita-pita yang muncul dengan ukuran tertentu dari masing-masing lot. Jarak pita diukur dari batas bawah sumur sampai batas bawah pita yang masih tampak. Nomor pita diurutkan dari jarak pita terdekat dengan batas bawah sumur. Pengukuran potongan DNA genom dilakukan dengan membandingkannya dengan berat molekul standar 100 bp DNA Ladder. Perbedaan antar nomor pada masing-masing lot ditunjukkan oleh jumlah pita dan jarak migrasinya.

Analisis data didasarkan pada ada atau tidaknya pita. Profil pita DNA diterjemahkan ke dalam data biner dengan ketentuan nilai 0 untuk tidak ada pita dan 1 untuk adanya pita DNA pada satu posisi yang sama dari individuindividu yang dibandingkan. Pengelompokan data matrik (cluster analysis) dan pembuatan dendrogram dilakukan dengan metode Unweighted Pair-Group Method Arithmetic (UPGMA) menggunakan program Pop Gene. Data matrik yang dihasilkan digunakan untuk memperoleh matrik kesamaan dengan menggunakan kesamaan yang sederhana melalui koefisien kesamaan Nei \& Li'S (Hilu, 1994; Fabri et al., 1995).

\section{HASIL DAN BAHASAN}

\section{Pengamatan Morfologi}

Hasil pengamatan morfologi induk ikan clown terdapat 3 band putih yang menyebar secara vertikal pada bagian kepala, badan, dan ekor serta tersambung melingkar secara utuh, sementara hasil pengamatan pada turunan F-1 menunjukkan adanya perbedaan pola band putih seperti tertera pada Tabel 1 .

Pada penelitian ini, rata-rata ukuran benih F-1 untuk masing-masing kelompok induk berkisar antara 1,60-3,36 cm. Pola band yang berkembang sempurna pada semua sampel hanya pada bagian kepala, sementara pola band putih di bagian badan yang muncul sempurna hanya terdapat pada 27 ekor sampel. Bahkan hampir semua sampel menunjukkan bahwa pola band putih pada bagian ekor belum muncul. Nampaknya pemunculan pola band putih pada benih ternyata dipengaruhi oleh umur/ukuran benih tersebut. Selanjutnya untuk mengetahui 
Tabel 1. Performansi pola band putih di bagian kepala, badan, dan ekor pada ikan clown turunan F-1

Table 1. White band pattern performance at head, body, and tail of clown fish first generation $(F-1)$

\begin{tabular}{|c|c|c|c|}
\hline \multirow{2}{*}{$\begin{array}{c}\text { Kode induk } \\
\text { Broodst ock } \\
\text { code }\end{array}$} & \multicolumn{3}{|c|}{$\begin{array}{l}\text { Jumlah individu F-1 (ekor) dengan performansi } \\
\text { Number of F-1 (ind.) with white band pattern performance }\end{array}$} \\
\hline & $\begin{array}{l}\text { Band putih pada kepala } \\
\text { White band at head }\end{array}$ & $\begin{array}{l}\text { Band putih pada badan } \\
\text { White band at body }\end{array}$ & $\begin{array}{l}\text { Band put ih pada ekor } \\
\text { White band at tail }\end{array}$ \\
\hline PT-2 & 10 & 1 & 0 \\
\hline PT-3 & 10 & 5 & 0 \\
\hline PT-5 & 10 & 8 & 1 \\
\hline PT-9 & 10 & 6 & 0 \\
\hline PT-10 & 10 & 7 & 0 \\
\hline
\end{tabular}

apakah perkembangan pola band ini dipengaruhi atau tidak secara genetik, maka dilakukan analisis DNA dengan metode RAPD.

\section{Analisis RAPD}

Penyeleksian primer yang akan digunakan untuk analisis RAPD ikan hias clown meng- gunakan dua puluh satu jenis primer yang mempunyai jumlah nukleotida sebanyak 10 nukleotida. Hasil seleksi ini menunjukkan bahwa 9 primer mampu menghasilkan produk amplifikasi (OPA-04, OPA-07, OPA-13, OPF-01, OPF-02, OPF-04, OPF-05, OPF-07, OPF-09) (Gambar 1).
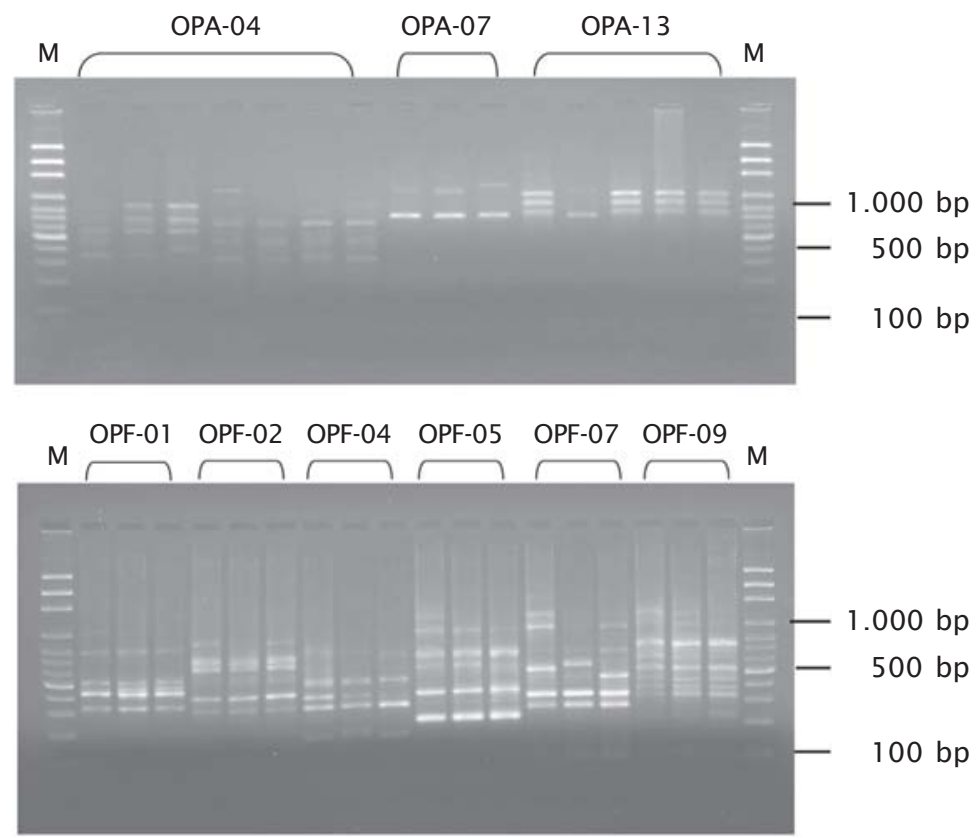

Gambar 1. Amplifikasi DNA ikan hias clown dengan menggunakan 9 primer RAPD (OPA04; OPA-07; OPA-1 3; OPF-01; OPF-02; OPF-04; OPF-05; OPF-07 dan OPF-09)

Figure 1. DNA amplification of clownfish using 9 primer RAPD (OPA-04; OPA-07; OPA13; OPF-01; OPF-02; OPF-04; OPF-05; OPF-07 and OPF-09) 
Tabel 2. Jenis primer, susunan basa dan jumlah pita DNA hasil amplifikasi

Table 2. Primer type, sequence base and number of DNA fragment amplicon

\begin{tabular}{|c|c|c|c|c|c|c|c|c|c|c|c|}
\hline \multirow[t]{2}{*}{$\begin{array}{c}\text { Primer } \\
\text { Primer }\end{array}$} & \multirow{2}{*}{$\begin{array}{l}\text { Susunan basa } \\
\text { Sequence } \\
\text { 5'- 3' }\end{array}$} & \multicolumn{5}{|c|}{$\begin{array}{l}\text { Jumlah pita } \\
\text { Number of } \\
\text { fragments }\end{array}$} & \multicolumn{5}{|c|}{$\begin{array}{c}\text { Jumlah pita polimorfik } \\
\text { Number of fragments } \\
\text { polymorphic }\end{array}$} \\
\hline & & PT-2 & PT-3 & PT-5 & PT-9 & PT-10 & PT-2 & PT-3 & PT-5 & PT-9 & PT-10 \\
\hline OPA-04 & AATCGGGCTG & 3 & 4 & 6 & 5 & 4 & 0 & 4 & 1 & 5 & 2 \\
\hline OPA-07 & GAAACGGGTG & 3 & 2 & 3 & 3 & 3 & 2 & 2 & 2 & 1 & 2 \\
\hline OPA-13 & CAGCACCCAC & 4 & 3 & 4 & 4 & 4 & 4 & 2 & 1 & 4 & 4 \\
\hline OPF-01 & ACGGATCCTG & 5 & 5 & 5 & 7 & 5 & 5 & 2 & 3 & 5 & 5 \\
\hline OPF-02 & GAGGATCCCT & 6 & 6 & 5 & 6 & 4 & 6 & 4 & 4 & 4 & 4 \\
\hline OPF-04 & GGTGATCAGG & 4 & 7 & 4 & 7 & 4 & 3 & 7 & 2 & 6 & 3 \\
\hline OPF-05 & CCGAATTCCC & 5 & 5 & 5 & 6 & 5 & 4 & 3 & 2 & 6 & 4 \\
\hline OPF-07 & CCGATATCCC & 7 & 8 & 7 & 6 & 6 & 7 & 8 & 7 & 6 & 6 \\
\hline OPF-09 & ССАAGCTTCC & 7 & 5 & 6 & 7 & 5 & 5 & 4 & 6 & 5 & 5 \\
\hline \multicolumn{2}{|c|}{ Total (Total) } & 44 & 45 & 45 & 51 & 40 & 36 & 36 & 28 & 42 & 35 \\
\hline \multicolumn{7}{|c|}{ Persentase polimorfisme } & 48.65 & 48.65 & 37.84 & 56.76 & 47.30 \\
\hline
\end{tabular}

Jumlah fragmen DNA hasil amplifikasi berkisar antara 6-10 pita tergantung pada primer dan karakter genetik ikan hias clown yang dianalisis. Ukuran fragmen yang diperoleh berkisar antara 100-1.500 bp. Dari 225 total fragment yang diproduksi oleh 9 primer, 177 fragmen $(78,66 \%)$ adalah polimorfik (Tabel 2). Jumlah fragmen DNA yang dihasilkan oleh setiap primer tergantung pada sebaran situs yang homolog dengan sekuen primer pada genom sampel yang diuji. Amplifikasi DNA terjadi jika primer menempel pada dua situs komplementer yang jaraknya berdekatan dan orientasinya saling terbalik. Jarak antar situs amplifikasi ini menghasilkan fragmen DNA dengan berbagai ukuran pasang basa. Umumnya jumlah pasang basa yang masih dapat diamplifikasi pada DNA genom suatu organisme berkisar 200 bp sampai 2.000 bp (Grattapaglia et al., 1992).

Tingkat atau level keragaman genetik yang ditunjukkan dengan jumlah fragmen/alel yang ditemui pada ikan clown yang diamati tidak jauh berbeda dibandingkan dengan keragaman genetik ikan laut lainnya yang mempunyai jumlah fragmen berkisar 6-17 (Nugroho, 2001 dalam Nugroho et al., 2003). Secara statistik (Nei, 1987), untuk rata-rata nilai keragaman genetik induk ikan clown dari semua lokus primer sebesar 0,253 sedangkan pada turunannya (F-1) adalah 0,157 . Nilai keragaman genetik ini masih menunjukkan nilai yang relatif tinggi dibandingkan dengan beberapa jenis ikan laut lainnya seperti pada ikan kerapu sunu, Plectropomus leopardus (Andamari et al., 2004) dan ikan napoleon, C. undulatus (Moria et al., 2005).

Primer OPA-07 yang digunakan untuk mengamplifikasi DNA ikan clown, menghasilkan pita polimorfis yang rendah (2-3 pita), sementara polimorfisme yang tinggi diperoleh dari primer OPF-07 (6-8) dan OPF-09 (5-7). Perbedaan jumlah dan polimorfisme pita DNA yang dihasilkan dari setiap primer menggambarkan kekomplekan karakter genom DNA ikan clown yang diamati (Grattapaglia et al., 1992). Karena pita DNA merupakan hasil berpasangannya nukleotida primer dengan nukleotida genom DNA ikan clown, maka semakin banyak primer akan semakin terwakili bagian-bagian genom DNA, sehingga semakin tergambar keadaan DNA ikan clown yang sesungguhnya. Sebaran situs penempelan primer pada genom DNA, jumlah fragmen yang diamplifikasi, serta kemurnian dan konsentrasi DNA genom dalam reaksi mempengaruhi intensitas pita DNA hasil amplifikasi (Grattapaglia et al., 1992). 

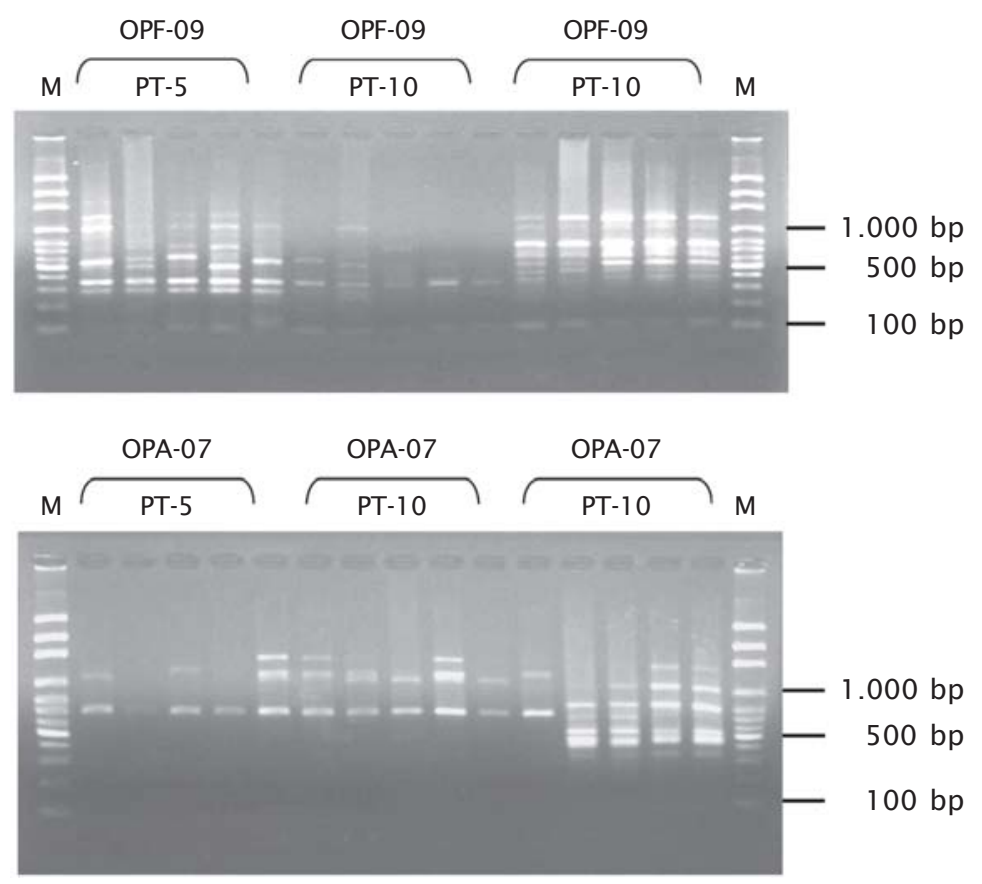

Gambar 2. Profil pita DNA ikan clown Lot PT-5 dan PT-10 hasil amplifikasi dengan menggunakan primer OPF-09 dan OPA-07

Figure 2. DNA fragment profile of clownfish at lot PT-5 and PT-10 amplified by using OPF-09 and OPA-07 primer

Tabel 3. Hasil perhitungan persentase perbedaan genetik antara induk ( $\mathrm{F}-0$ ) terhadap turunannya (F-1) dengan menggunakan 9 primer RAPD

Table 3. Results of genetic differences calculation between F-O population and its generations (F-1) using 9 primer RAPD

\begin{tabular}{|c|c|c|c|c|c|c|c|}
\hline \multirow{2}{*}{$\begin{array}{l}\text { Lokus } \\
\text { Locus }\end{array}$} & \multirow{2}{*}{$\begin{array}{c}\text { Fragmen } \\
\text { Fragment (bp) }\end{array}$} & \multicolumn{5}{|c|}{$\begin{array}{l}\text { Persentase perbedaan genetik } \\
\text { Percentage of genet ic differences (\%) }\end{array}$} & \multirow{2}{*}{$\begin{array}{c}\text { Total } \\
\text { Total } \\
(\%)\end{array}$} \\
\hline & & PT- $2^{*}$ & PT- $3^{*}$ & PT-5 $5^{*}$ & PT-9* & PT-10" & \\
\hline OPA-04 & $300 ; 500 ; 700$ & 0 & 15.0 & 0 & 4.0 & 0 & 19.0 \\
\hline OPA-07 & $700 ; 1300 ; 1500$ & 0 & 5.0 & 6.0 & 3.0 & 20.0 & 34.0 \\
\hline OPA-13 & $500 ; 800 ; 1000$ & 0 & 6.0 & 0 & 5.0 & 5.0 & 16.0 \\
\hline OPF-01 & $400 ; 500 ; 800 ; 1500$ & 2.0 & 0 & 4.0 & 3.0 & 0 & 9.0 \\
\hline OPF-02 & $300 ; 400 ; 500 ; 600 ; 800$ & 3.0 & 0 & 4.0 & 2.0 & 5.0 & 14.0 \\
\hline OPF-04 & $200 ; 300 ; 400 ; 500 ; 600 ; 700$ & 2.0 & 2.0 & 10.0 & 11.0 & 2.0 & 27.0 \\
\hline OPF-05 & $200 ; 300 ; 500 ; 700 ; 800 ; 1000$ & 6.0 & 0.0 & 2.0 & 8.0 & 6.0 & 22.0 \\
\hline OPF-07 & $200 ; 300 ; 400 ; 500 ; 700 ; 800$ & 2.0 & 3.0 & 1.5 & 5.0 & 3.0 & 14.5 \\
\hline OPF-09 & $400 ; 500 ; 600 ; 700 ; 800 ; 1000 ; 1200$ & 1.0 & 8.0 & 13.0 & 7.0 & 12.0 & 41.0 \\
\hline
\end{tabular}

Keterangan: "Kode induk (F-0) ikan hias clown dan kolom dibawahnya menunjukkan besarnya nilai perbedaan genetik terhadap F-1

Note: "Broodstock code (F-O) of clown fish and column below of each showed the values of genetic differences toward its $F-1$ 
Berdasarkan profil pita DNA hasil amplifikasi dengan menggunakan 9 primer, ditemukan adanya perbedaan genetik antara individu induk (F-0) terhadap turunannya (F-1) (Gambar 2 dan Tabel 3).

Profil pita DNA dari 60 individu yang diamplifikasi menunjukkan bahwa pada primer OPF-09 dan OPA-07, teramati ada perbedaan genetik $\mathrm{F}-0$ terhadap $\mathrm{F}-1$ yang cukup tinggi sebesar 34,0\% (OPA-07) dan 41,0\% (OPF-09) (Tabel 3). Hal ini membuktikan bahwa ternyata pada beberapa F-1 ikan clown menunjukkan adanya perbedaan morfologi (warna) dengan induknya (F-0). Walaupun persentase ketidaksesuaian antara F-0 terhadap F-1 pada primer OPF-09 dan OPA-07 cukup tinggi dibandingkan primer RAPD lainnya, namun kedua primer tersebut perlu dibuktikan lagi dengan analisis keterpautan genetik karena tingkat artefactual variation dari penanda RAPD yang sangat tinggi, yaitu adanya pita yang nonparental (Ellsworth et al., 1993; Micheli et al., 1993).

Dengan ditemukan adanya perbedaan keragaman genetik antara F-0 terhadap F-1 pada primer OPF-09 dan OPA-07, diduga ada terjadi penurunan variasi gen yang akan berakibat hilangnya alel yang mengontrol warna, pertumbuhan, dan ketahanan terhadap penyakit sehingga akhirnya akan berakibat fatal bagi generasi berikutnya. Hal ini sesuai dengan pendapat Leary et al., 1984; Agnese et al., 1995; Kincaid, 1993; yang menyatakan bahwa penurunan variasi gen akibat hilangnya alel-alel langka dari hasil perbenihan dapat menghambat pertumbuhan, rentan terhadap serangan penyakit dan perubahan lingkungan serta terjadinya abnormalitas benih yang dihasilkan.

\section{KESIMPULAN}

- Performansi pola band putih pada ikan clown berkaitan dengan karakter genetik dan dapat dipengaruhi oleh pertambahan umur benih.

- Nilai rata-rata keragaman genetik pada induk ikan clown dari semua lokus primer sebesar 0,253 ; sedangkan pada turunannya ( $\mathrm{F}-1$ ) adalah 0,157.

- Persentase perbedaan genetik tertinggi antara F-0 terhadap generasi F-1 terdapat pada lokus primer OPF-09 dan OPA-07 sebesar $41,0 \%$ dan $37,0 \%$.

\section{SARAN}

Perlu dilakukan penelitian lebih lanjut mengenai sekuen gen pengontrol warna ikan clown dengan menggunakan lokus OPA07 dan OPF-09 sebagai informasi dasar karena pita (fragmen) DNA yang teramati merupakan hasil pasangan nukleotida primer dengan nukleotida gen ikan clown.

\section{DAFTAR ACUAN}

Agnese, J.F., Oteme, Z.J., \& Gilles, S. 1995. Effect of domestication on genetic variability, fertility survival and growth rate in tropical siluriform (Heterobranchus longifilis, Valenciemes 1840). Aquaculture, 131: 197-204.

Andamari, R., Haryanti, Suwirya, K., Moria, S.B., \& Permana, I G.N. 2004. Bioreproduksi dan karakteristik variasi genetik ikan kerapu sunu, Plectropomus leopardus. Laporan Teknis Proyek Riset Perikanan Budidaya Laut Gondol-Bali. Balai Besar Riset Perikanan Budidaya Laut Gondol-Bali, $12 \mathrm{hlm}$.

Ellsworth, D.L., Rittenhouse, K.,\& Honycutt, R.L. 1993. Artefactual variation in randomly amplified polymorphic DNA banding patterns. Biotechniques, 14: 214-217.

Fabri, A., Hormaza, J.I., \& Plito, V.S. 1995. Random Amplified Polymorphic DNA analysis of Olive (Olea europaea L.) cultivars. J. Amer. Soc. Hort. Sci.,120(3): 538-542.

Grattapaglia, D., Chaparro, J., Wilcox, P., McCord, S., Werner, D., Amerson, H., McKeand, S., Bridgwater, F., Whetten, R., O'Malley, D., \& Sederoff, R. 1992. Mapping in woody plants with RAPD markers: Application to breeding in forestry and holticulture, di dalam: Application of RAPD Technology to Plant Breeding. Joint Plant Breeding Symposia Series CSSA/ASHS/AGA. Minneapolis, 1 November 1992, p. 37-40.

Hilu, K.W. 1994. Evidence from RAPD Markers in evolution of Echinocloa millets (Poacea). PI. Syst. Evol., 189: 247-257.

Kincaid, H.L. 1983. Inbreeding in fish population used for aquaculture. Aquaculture, 33: 215-227.

Leary, R.F., Allendorf, F.W., \& Knudsen K.L. 1984. Superior Developmental Stability of Heterozygotes at Enzyme Loci in Salmonid Fishes. Am. Nat., 124: 540-551. 
Martosewojo, S., Adrim, M., Malikusworo, H., \& Burhanuddin. 1985. Sumberdaya ikan hias laut. Seri Sumber Daya Alam. LON LIPI, 7 hlm

Micheli, M., Bova, R., Pascale, E., \& D’Ambrosio, E. 1993. Reproducible DNA fingerprinting with the random amplified polymorphic DNA (RAPD) method. Nucleic Acids Res., 22: 1921-1922.

Moria, S.B., Haryanti, Permana, I G.N., I.K. Wardana, \& Slamet, B. 2005. Studi Pendahuluan karakter genetik ikan napoleon, Cheilinus undulatus dengan metode Restriction Fragment Length Polymorphism (RFLP) mt-DNA. Prosiding Seminar Nasional Hasil Penelitian Perikanan dan Kelautan Tahun 2005. Yogyakarta $30 \mathrm{Juli}$, hlm. 48-54.

Nei, M. 1987. Molecular Evolutionary Genetics. Columbia University Press. New York, 512 pp.
Nkongolo, K.K., Michael, P., \& Gatton, W.S. 2002. Identification and characterization of RAPD markers inferring genetic relationships among Pine species. Genome, 45: 51-58.

Nugroho, E., Hadi, W., \& Sudarto. 2003. Variasi genetik ikan baung, Mystus nemurus dari beberapa waduk di Jawa yang dianalisis dengan marker Mitokondria D-Loop. J. Pen. Perik. Indonesia, 9(1): 1-5.

Ovenden, J. 2000. Development of restriction enzyme markers for red snapper (Lutjanus erythropterus and Lutjanus malabaricus) stock descrimination using genetic variation in mitochondria DNA. Moleculer Fisheries Laboratory, Southern Fisheries Centre.

Sambrook, J., Fritsh, E.F., \& Maniatis, T. 1989. Molecular cloning. Cold Spring Harbor Laboratory Press, New York, p. 568-500. 